\title{
A szív MR-vizsgálat szerepe kevert típusú (humorális és celluláris) kardiális allograft rejekció esetén
}

\author{
Suhai Ferenc Imre', Sax Balázs', Assabiny Alexandra', Király Ákos', \\ Czimbalmos Csilla', Csécs Ibolya', Kovács Attila', Lakatos Bálint', \\ Németh Endre², Becker Dávid', Szabolcs Zoltán', Hubay Márta³, Merkely Béla', \\ Vágó Hajnalka'
}

Semmelweis Egyetem, ${ }^{1}$ Városmajori Szív- és Érgyógyászati Klinika, ${ }^{2}$ Aneszteziológiai és Intenzív Terápiás Klinika, ${ }^{3}$ Igazságügyi és Biztosítás-orvostani Intézet, Budapest

Levelezési cím: suhaiimi987@gmail.com

Az akut kardiális allograft rejekció a modern immunszuppresszív terápia ellenére jelenleg is az egyik vezető halálok szívtranszplantált betegek körében. Az akut rejekció kimutatásának referenciamódszere az endomiokardiális biopszia, azonban a noninvazív képalkotó diagnosztikus eljárások napjainkban e témában a tudományos kutatások fókuszába kerültek. A szív MR- (CMR) vizsgálat a bal és jobb kamra globális és regionális funkció meghatározásán túl szöveti karakterizációs képessége miatt kiemelkedik ezen modalitások közül. A kevert típusú (celluláris és humorális) rejekció ritka entitás, amelyről csak kevés irodalmi adat áll rendelkezésünkre, diagnosztikája sok esetben kihívást jelenthet. A kevert rejekció okozta CMR-eltérésekröl nagyon korlátozottak az ismereteink. Az elmúlt évben három szívtranszplantált betegnél akut kevert típusú rejekciót diagnosztizáltunk, az elvégzett CMR-vizsgálat mindhárom beteg esetében nagyon hasonló eltéréseket mutatott. Egy beteg esetén kontroll CMR-vizsgálatokat is végeztünk, nyomon követve a bal és jobb kamrai ejekciós frakciók, volumenek, valamint az ödéma és késői kontraszthalmozás mintázatának változását a kezelés függvényében.

A kutatás az „NVKP_16-1-2016-0017 számú projekt a Nemzeti Kutatási Fejlesztési és Innovációs Alapból biztosított támogatással, az NVKP_16 pályázati program finanszírozásában valósult meg.

Kulcsszavak: szívtranszplantáció, szív mágneses rezonancia, kevert típusú rejekció

The role of CMR in the evaluation of acute mixed cardiac allograft rejection

Despite of the modern immunosuppressive therapy the acute cardiac allograft rejection is a leading cause of morbidity and mortality in heart transplant patients. Endomyocardial biopsy is considered the current gold standard for the diagnosis of acute cardiac rejection, nevertheless there is an intense research regarding on non-invasive diagnostic methods in this field. Cardiac magnetic resonance imaging (CMR) has an evolving role in the detection of acute rejection among these modalities because of its ability to quantify ventricular function and characterize the complete myocardial tissue. There are only few data of the mixed (cellular and humoral) rejection which is a very rare entity, and the diagnosis remains challenging. Our knowledge about the CMR findings of mixed cardiac rejection is limited as well. In the last year we have made a diagnosis of mixed cardiac rejection in three patients, and the subsequently performed CMR showed very similar features in each patients. We performed serial CMR examinations in one patient to follow-up the changes of left and right ventricular volumes, ejection fractions and the pattern of myocardial oedema and delayed contrast enhancement. Project no. NVKP_16-1-2016-0017 has been implemented with the support provided from the National Research, Development and Innovation Fund of Hungary, financed under the NVKP_16 funding scheme."

Keywords: heart transplantation, cardiac magnetic resonance, mixed cardiac rejection 


\section{Bevezetés}

A szívtranszplantáció (HTX) a végstádiumú szívelégtelenség kezelésének hatékony és eredményes kezelési módja. Az immunszuppresszív terápia fejlődésével a szívtranszplantált betegek túlélése jelentősen javult, azonban a napjainkban alkalmazott korszerü immunszuppresszív és immunmoduláns terápia ellenére az akut kardiális rejekció (AR) még mindig vezető halálok a szívtranszplantált betegek körében. Az AR előfordulása a transzplantációt követő első évben a legmagasabb, a különböző irodalmi adatok alapján 21-70\% között mozog (1-4), amelyhez jelenleg is magas $12 \%$-os mortalitás párosul $(1,4)$.

Az AR hátterében leggyakrabban T-sejt mediálta celluláris rejekció (CR) áll, amely előfordulhat napokkal, hónapokkal, évekkel a HTX után is, azonban az első hat hónapban-egy évben a leggyakoribb (2). Az antitest mediálta (humorális) rejekció (AMR) egy kevésbé jól ismert és nehezebben jellemezhető entitás, amely az előzőhöz képest rosszabb prognózissal, magasabb mortalitással, valamint a kardiális allograft vasculopathia (KAV) és allograft-diszfunkció gyakoribb előfordulásával jár (5). Az antitest mediálta akut rejekció pontos incidenciája nem ismert, irodalmi adatok az előfordulási gyakoriságát 7,8-25\% közé teszik, a HTX-t követő néhány évben a leggyakoribb (6-8). Mind a CR és mind az AMR diagnosztikája az endomiokardiális biopsziás mintában (EMB) látott hisztológiai és immunhisztokémiai eltéréseken alapszik, a nemzetközi Szív- és Tüdőtranszplantációs Társaság (ISHLT) által meghatározott kritériumoknak megfelelően (9-11). Míg a celluláris rejekció egy jól definiált klinikopatológiai entitás, addig az antitest mediálta rejekció diagnosztikája esetenként ma is kihívást jelenthet mind a patológusok, mind klinikusok számára (12). Az antitest mediálta rejekció megítélésére 2010-ben az ISHLT Konszenzus Konferencia foglalta össze a szövettani és immunhisz- tokémiai jellegzetességeket, amelyet 2013-ban módosították. A hisztopatológiai kritériumok a következők:

- a kapillárisokban és venulákban látható aktivált mononukleáris sejtek,

- az endothelsejtek duzzanata,

- a szövetközti térben ödéma.

- vérzés, szívizomsejt-elhalás, kapilláris fragmentáció vagy intravaszkuláris mikrotrombusok súlyos AMR-re utalnak.

Az AMR irányában végzett immunopatológiai vizsgálat általában C4d és CD68 elleni antitest reakciót jelent, előbbi esetén a kapilláris endothel több mint 50\%-os erős pozitivitása jelent pozitív C4d eredményt, utóbbira pedig a kapillárisok lumenében CD68 pozitív makrofágok jelenléte jellemző (13).

Amennyiben a celluláris és antitest mediálta rejekció együtt van jelen ún. kevert típusú rejekcióról beszélhetünk (MR). A kevert típusú rejekcióról csak csekély mennyiségú és döntően kis elemszámú irodalmi adat áll rendelkezésünkre $(7,8,14,15)$, így még az sem tisztázott, hogy önálló entitásként kezelhető-e, vagy celluláris rejekcióhoz társuló AMR, esetleg antitest mediálta rejekcióhoz társuló CR-ről van-e szó (8). A viszonylag ritka előfordulás és a korlátozott irodalmi adatok miatt a kevert típusú rejekcióról, a noninvazív képalkotó vizsgálati módszereiről, illetve az azokon látható eltérésekről csak kevés adat áll rendelkezésünkre.

\section{Saját tapasztalataink a Városmajori Szív- és Érgyógyászati Klinikán}

Az elmúlt év során a Városmajori Szív- és Érgyógyászati Klinikán általunk gondozott szívtranszplantált betegek közül három esetben diagnosztizáltunk EMB-vel igazolt kevert típusú akut rejekciót. Az ambuláns kontrollvizsgálat során végzett echokardiográfiás vizsgálat mindhárom beteg esetén csökkent bal kamra szisztolés funkciót írt le, amely hátterében akut rejekció gyanúja

1. TÁBLÁZAT. A betegek klinikai és echokardiográfiás adatai a kevert rejekció felismerésének időpontjában (HTX=szívtranszplantáció, DCM= dilatatív cardiomyopathia)

\begin{tabular}{|c|c|c|c|}
\hline & 1. beteg & 2. beteg & 3. beteg \\
\hline HTX oka & Idiopátiás DCM & Idiopátiás DCM & Iszkémiás szívbetegség \\
\hline $\begin{array}{l}\text { Kevert rejekció és } \\
\text { HTX között eltelt idő }\end{array}$ & 27 hónap & 18 hónap & 115 hónap \\
\hline Klinikum, panaszok & $\begin{array}{l}\text { Enyhén csökkent } \\
\text { terhelhetőség }\end{array}$ & $\begin{array}{l}\text { Effort dyspnoe } \\
\text { szupraventrikuláris tahycardia }\end{array}$ & Panaszmentes \\
\hline $\begin{array}{l}\text { Immunszuppresszív } \\
\text { terápia }\end{array}$ & $\begin{array}{l}\text { Mikofenolát, és takrolimusz } \\
\text { (normál tartományban) }\end{array}$ & $\begin{array}{l}\text { Mikofenolát, és takrolimusz } \\
\text { (normál tartományban) }\end{array}$ & $\begin{array}{l}\text { Mikofenolát, metilprednizolon és } \\
\text { takrolimusz (normál tartományban) }\end{array}$ \\
\hline pro BNP-szint (pg/ml) & 2177 & 3375 & 1985 \\
\hline \multicolumn{4}{|l|}{ Echokardiográfia } \\
\hline - Falmozgások & Diffúz bal kamrai hipokinézis & Diffúz bal kamrai hipokinézis & Diffúz bal kamrai hipokinézis \\
\hline • Szisztolés funkció & $\begin{array}{l}\text { Enyhén csökkent szisztolés } \\
\text { balkamra-funkció }\end{array}$ & $\begin{array}{l}\text { Közepes fokban csökkent bal } \\
\text { és enyhén csökkent szisztolés } \\
\text { jobbkamra-funkció }\end{array}$ & $\begin{array}{l}\text { Enyhén csökkent szisztolés } \\
\text { balkamra-funkció }\end{array}$ \\
\hline - Diasztolés funkció & Megtartott & Megtartott & Megtartott \\
\hline
\end{tabular}


2. TÁBLÁZAT. A betegek első szív MR-vizsgálatuk során mért MR-paraméterek adatai (EDVi=végdiasztolés volumenindex*; $\mathrm{ESV}^{*}=$ végszisztolés volumenindex; $\mathrm{SVi}^{*}=$ verővolumen-index; $E F=$ ejekciós frakció, Mi*= izomtömegindex, *Testfelszínre indexált adatok

\section{\begin{tabular}{l|l|l} 
1. beteg & 2. beteg 3 . beteg
\end{tabular}}

Bal kamra (LV)

LVEDVi $\left(\mathrm{ml} / \mathrm{m}^{2}\right)$

LVESVi $\left(\mathrm{ml} / \mathrm{m}^{2}\right)$

LVSVi $\left(\mathrm{ml} / \mathrm{m}^{2}\right)$

LVEF (\%)

LVMi $\left(\mathrm{g} / \mathrm{m}^{2}\right)$

Jobb kamra (RV)

RVEDVi $\left(\mathrm{ml} / \mathrm{m}^{2}\right)$

RVESVi $\left(\mathrm{ml} / \mathrm{m}^{2}\right)$

RVSVi $\left(\mathrm{ml} / \mathrm{m}^{2}\right)$

RVEF (\%)

\begin{tabular}{l}
86 \\
54 \\
32 \\
37 \\
55 \\
\hline 68 \\
\hline 33 \\
35 \\
51
\end{tabular}

\begin{tabular}{l}
93 \\
66 \\
27 \\
29 \\
83 \\
\hline 61 \\
\hline 35 \\
26 \\
43
\end{tabular}

\begin{tabular}{l}
78 \\
46 \\
32 \\
41 \\
83 \\
\hline 86 \\
\hline 50 \\
35 \\
41
\end{tabular}

merült fel. Egy esetben szupraventrikuláris ritmuszavar vetette fel a kilökődés gyanúját. A betegek klinikai és echokardiográfiás adatait az 1. táblázat foglalja öszsze. A szív MR-vizsgálatokat a bal és jobb kamrai volumenek pontos meghatározása, az esetleges ödémás/ nekrotikus myocardium megítélése céljából végeztük. A CMR-vizsgálat mindhárom beteg esetén nagyon hasonló képet mutatott: normál tartományban levő bal és jobb kamrai végdiasztolés és végszisztolés volument, jelentös-közepes fokban csökkent bal kamrai ejekciós frakciót, csökkent bal kamrai verővolument. A jobb kamrai ejekciós frakció egy esetben jó, két esetben közepes fokban csökkent volt (2. táblázat). Enyhe diffúz bal kamrai hipokinézis mellett a T2-súlyozott felvételeken az interventrikuláris szeptum jobb kamrai felszínét érintő, a bal kamra anterior falára részben ráterjedő, valamint az alsó és felső inzerciós zónát érintő markáns ödémás jelfokozódás ábrázolódott. Ödémás jel-

fokozódás volt látható a jobb kamra szabad falán és rekeszi felszínén is. Kontrasztanyag beadását követöen miokardiális nekrózist/fibrózist jelző késői típusú kontraszthalmozás alakult ki az ödémás területeken, továbbá a bal kamra inferior és laterális fala mentén, valamint a jobb kamra rekeszi felszíne és szabad fala mentén markáns perikardiális halmozással (1. ábra). A látott MR-eltérések szívizomgyulladásra nem voltak típusosak, az irodalmi adatokat áttekintve elsősorban akut rejekció lehetösége merült fel. A szövettani vizsgálatok az elvégzett EMB alapján mindhárom betegnél celluláris és humorális komponensű kevert rejekciót mutatott. A kevert típusú rejekció a transzplantációt követő második, harmadik és tízedik évben jelentkezett.

Egy beteg esetén további kontroll szív MR-vizsgálatokat is végeztünk a rejekciós folyamat és a bal és jobb kamra volumenek, ejekciós frakciók nyomon követésére, esetét a következőkben részletesebben ismertetjük.

\section{Esetismertetés}

L.A. 30 éves férfi betegnél 2014.11.22-én végeztek ortotopikus szívtraszplantációt idiopátiás dilatatív cardiomyopathia miatt. A korai posztoperatív időszak eseménytelenül zajlott, az echokardiográfia végig jó graftfunkciót igazolt. A transzplantációt követő első évben végzett rutinszerü EMB-k és az echokardiográfiás vizsgálatok rejekcióra utaló eltérést nem igazoltak. 2017 márciusában külföldi utazást követően a beteg enyhén csökkent terhelhetőségröl számolt be, a rutin ambuláns kontroll során végzett echokardiográfiás vizsgálat közepes fokban csökkent szisztolés balkamra-funkciót írt le, diffúz hipokinézis talaján. A csökkent graftfunkció hátterében koronarográfiás vizsgálat KAV-ot nem igazolt. Az echokardiográfiás vizsgálat és a klinikum alapján akut rejekció és szívizomgyulladás lehetősége is felmerült, emiatt került sor az első szív MR-vizsgá-

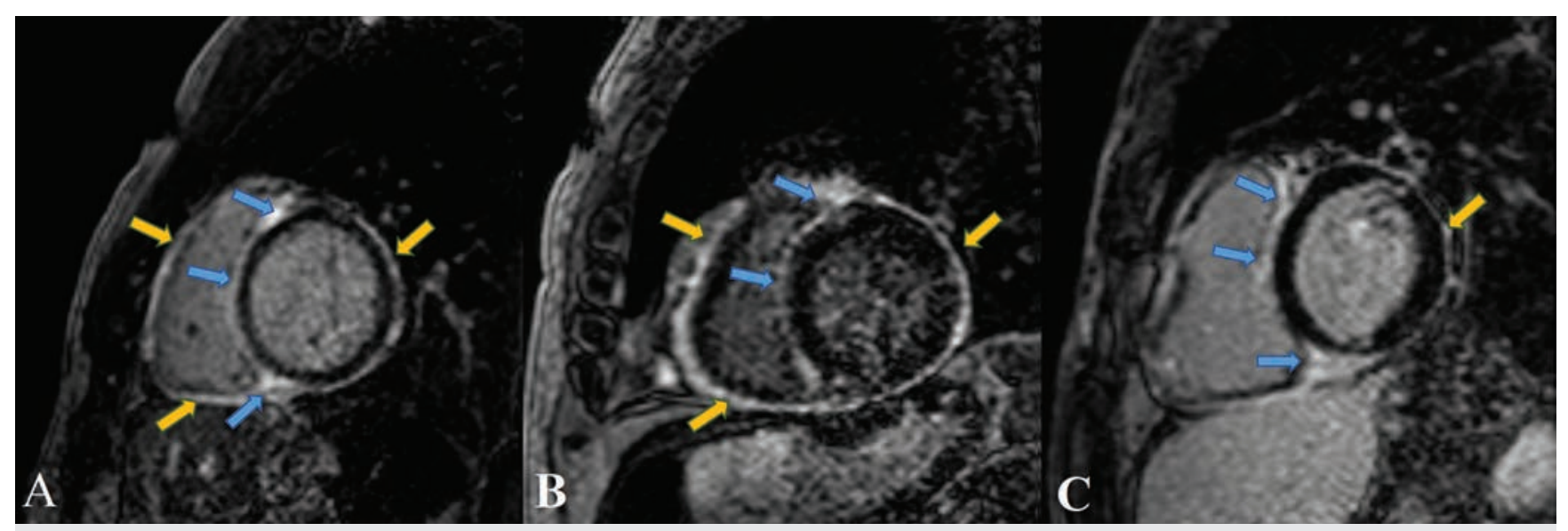

1. ÁBRA. Három kevert típusú akut kardiális rejekció miatt vizsgált beteg (A-C) rövidtengelyi késői kontraszthalmozásos MR képe. Az interventrikuláris szeptum jobb kamrai felszínét érintő, a bal kamra anterior falára részben ráterjedő, valamint az alsó és felső inzerciós zónát érintő késői halmozás figyelhető meg (kék nyilak), amelyhez a bal kamra lateralis fala mentén, valamint a jobb kamra rekeszi felszíne és szabad fala mentén markáns perikardiális halmozás társul (sárga nyilak) 


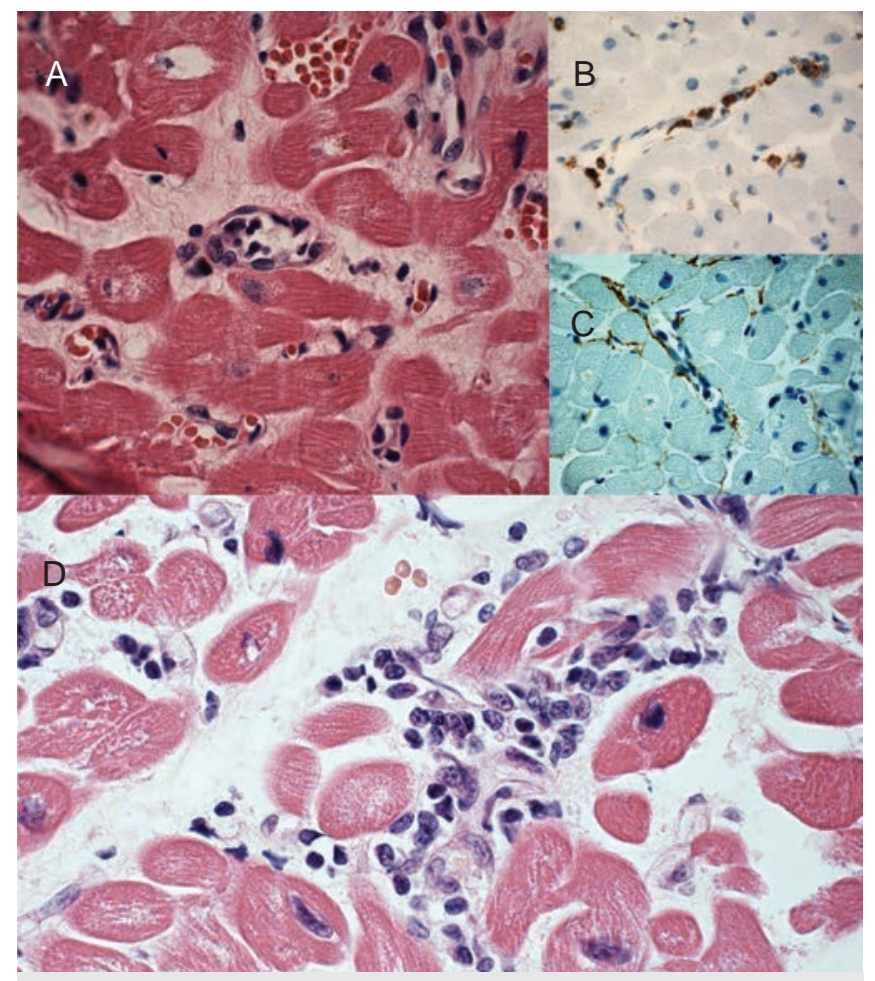

2. ÁBRA. 1. beteg akut kevert típusú rejekciójának szövettani képe. Humorális $(A-C)$ és celluláris $(D)$ rejekció (A: H-E festés 63x; B: CD 68 immunhisztokémiai reakció intrakapilláris makrofágokkal 63x; C: C4d immunhisztokémiai reakció, komplementkötődés a kapilláris endothel felszínén 40x)

latra. A CMR során közepes fokban csökkent bal és jobb kamrai ejekciós frakciókat, csökkent verővolumeneket mértünk (1. táblázat). Az interventrikuláris szeptum jobb kamrai felszínét, az alsó és felső inzerciós zónát, valamint a jobb kamra szabad falát és rekeszi felszínét érintő markáns ödémás jelfokozódás és késői kontraszthalmozás ábrázolódott (2. ábra). Az elvégzett EMB ISHLT Gr I-II celluláris rejekciót igazolt, a kimutatott donorellenes antitestek jelenléte ellenére szövettanilag humorális komponens még nem volt kimutatható. $A z$ első CMR-vizsgálatot követően három héttel, két hónappal és négy hónappal később kontroll CMR-eket végeztünk. Az első kontrollvizsgálatot követően a beteg szteroid lökésterápiában és keringő donor specifikus antitestek jelenléte miatt plazmaferezisben részesült. A két héttel későbbi kontroll EMB a celluláris rejekció enyhe javulását mutatta (grade IR), azonban a három héttel későbbi kontroll CMR érdemi változást nem mutatott (3. táblázat). Egy hónappal az első biopsziás mintavételt követően az EMB már grade 2 humorális rejekciót is mutatott a celluláris komponens mellett (ISHLT gr. IR. pAMR II), ekkor ismét plazmaferezis, valamint extrakorporális és fotoferezis terápia indult, illetve egy hónapon keresztül mitigált dózisú rituximab kezelést kapott. Két hónappal az első rejekciós mintát követően végzett EMB során a már enyhe celluláris rejekció perzisztált, a humorális rejekció aktivitása csökkent (ISHLT grade IR. pAMR I) (2. ábra). Az elvégzett kontroll CMR a bal kamra ejekciós frakció minimális javulását írta le, amely mellett a bal kamrai interventrikuláris szeptumot, az alsó és felső inzerciós zónát, valamint a jobb kamra szabad falát és rekeszi felszínét érintő késői halmozás szintén perzisztált, a markáns ödéma továbbra is ábrázolódott. A négy hónapos kontroll EMB eredménye a humorális komponens tekintetében kis javulást mutat (grade IR. pAMR I - $\mathrm{H}+$ ) a kontroll CMR során bal és jobb kamrát érintő, ödémával és késői kontraszthalmozással járó rejekciós folyamat kiterjedése és intenzitása kissé csökkent (3. ábra), a bal kamrai ejekciós frakció újabb 6\%-ot javult, a bal kamrai verővolumen kissé növekedett, a többi paraméter érdemben nem változott (3. táblázat). A beteg jelenleg tünet- és panaszmentes, azonban legutóbbi szövettani mintájában még humorális rejekcióra utaló eltérések megmaradtak, míg a celluláris rejekcióra utaló eltérés már nem ábrázolódott. A donorspecifikus antitestek eltűntek a keringésből.

\section{Az akut rejekció diagnosztikájának rövid irodalmi áttekintése \\ Endomiokardiális biopszia (EMB)}

Az akut rejekció diagnosztikájának jelenleg is az endomiokardiális biopszia a referenciamódszere. Intézeti protokollunk alapján az első évben regulárisan végzett biopsziás mintavételek célja az akut rejekció mielőbbi kimutatása, ennek köszönhetően az AR általában tü-

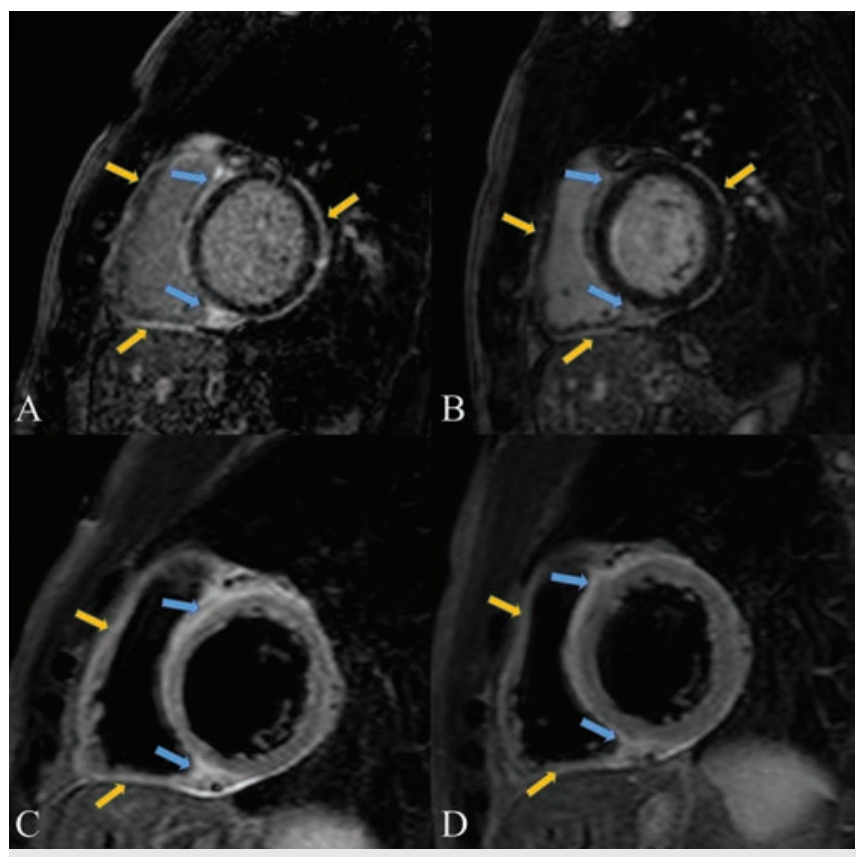

3. ÁBRA. L.A. beteg identikus rövidtengelyi késői kontraszthalmozásos (felső sor) és vérelnyomásos $T_{2}$ súlyozott SPIR a TSE felvételei (alsó sor), az első MR-vizsgálat $(A, C)$ valamint a négy hónapos kontroll $M R$ során $(B, D)$. Jól látható hogy a bal kamrai interventrikuláris szeptumot, az alsó és felső inzerciós zónát, valamint a jobb kamra szabad falát és rekeszi felszínét érintő késői halmozás és miokardiális ödéma kiterjedése és intenzitása csökkent a kontroll felvételeken. 
3. TÁBLÁZAT. 1. beteg első, valamint 3 hétnél, 2 hónapnál és 4 hónapnél végzett szív MR-vizsgálatának adatai (Rövidítések: $E D V i=$ végdiasztolés volumenindex*; $E S V{ }^{*}=$ végszisztolés volumenindex; $\mathrm{SVi}^{\star}=$ verővolumen-index; $\mathrm{EF}=$ ejekciós frakció, Mi*=izomtömegindex, ${ }^{*}$ Testfelszínre indexált adatok

első CMR 3 hét 2 hónap 4 hónap

Bal kamra (LV)

\begin{tabular}{lllll|}
\hline LVEDVi $\left(\mathrm{ml} / \mathrm{m}^{2}\right)$ & 86 & 87 & 78 & 79 \\
\hline LVESVi $\left(\mathrm{ml} / \mathrm{m}^{2}\right)$ & 54 & 54 & 45 & 40 \\
\hline LVSVi $\left(\mathrm{ml} / \mathrm{m}^{2}\right)$ & 32 & 33 & 33 & 39 \\
\hline LVEF $(\%)$ & 37 & 38 & 43 & 49 \\
\hline LVMi $\left(\mathrm{g} / \mathrm{m}^{2}\right)$ & 55 & 55 & 55 & 60 \\
\hline Jobb kamra (RV) & & & & \\
\hline RVEDVi $\left(\mathrm{ml} / \mathrm{m}^{2}\right)$ & 68 & 67 & 55 & 56 \\
\hline RVESVi $\left(\mathrm{ml} / \mathrm{m}^{2}\right)$ & 33 & 33 & 21 & 23 \\
\hline RVSVi $\left(\mathrm{ml} / \mathrm{m}^{2}\right)$ & 35 & 34 & 32 & 33 \\
\hline RVEF $(\%)$ & 51 & 51 & 61 & 59
\end{tabular}

netmentesen kerül felismerésre. A klinikai tünetek kialakulásának hátterében a rejekció során létrejövő graftdiszfunkció áll (3). A leggyakoribb panasz a nyugalmi vagy terhelésre jelentkező diszpnoé, paroxizmális nokturnális diszpnoé, palpitáció, presyncope, syncope, perifériás ödéma. Az EMB-t gyakorlott intervenciós szakemberek végzik, így a szövődményrátája minimális. $A z$ EMB limitációjának az alábbiak tekinthetőek:

- invazív eljárás;

- ionizáló sugárzással jár, valamint

- ritka, de súlyos szövődményekkel járhat: tamponád, tartós ingerületvezetési zavar,

- az ismételt mintavételek kapcsán miokardiális fibrózis és vénatrombózis alakulhat ki;

- fals negatív eredményt adhat (16-20).

A 2010-es ISHLT konszenzus konferencia előtt a biopszia negatív rejekciós betegek aránya 10-20\% között mozgott, ami az AMR diagnosztikájának bevezetése után csökkent (21), de továbbra sem elhanyagolható mértékű. Diagnosztikus nehézséget okozhat még a nem megfelelő méretű biopsziás szövet, vagy ha szívizom helyett véralvadék, fibrózis, vagy esetlegesen elöző biopszia területe kerül kivételre. Utóbbi esetben a szöveti kép heveny celluláris rejekciót utánozhat. Epikardiális sejtek jelenléte esetleges perforáció lehetőségére hívja fel a figyelmet. A transzplantáció utáni korai periódusban ún. perioperatív iszkémia dominálhatja a szöveti képet (22).

\section{Noninvazív képalkotó diagnosztika}

\section{Echokardiográfia}

Az echokardiográfia könnyen kivitelezhető, elterjedt, gyors non-invazív vizsgálómódszer, amelynek az AR diagnosztikájában betöltött szerepét számos korábbi tanulmány vizsgálta. Akut rejekció során általában elő- ször a diasztolés, majd a szisztolés funkció romlását figyelhetjük meg. Az olyan hagyományos paraméterek, mint a bal kamrai izomtömeg, ejekciós frakció (EF), vagy falvastagság nem bizonyultak kellően szenzitívnek az AR felismerésében (23). Néhány tanulmányban az izovolumetriás relaxációs idő (IVRT) (24-26), a csúcs telődési hányados (27) és a miokardiális perfomance index (28), valamint a korai és késői diasztolés mitralis annulus sebesség ( $E_{m}$ és $\left.A_{m}\right)(29)$ szignifikáns, ám változó mértékü korrelációt mutatott az akut rejekcióval. Egy, a különböző echokardiográfiás paraméterek diagnosztikus teljesítményét összegző metaanalízisben (29) nem találtak egyetlen olyan paramétert sem, amely mindegyik tanulmányban egyöntetűen megbízható lett volna az AR diagnosztikájában. A 2D speckle tracking echokardiográfia alkalmas a szív globális és regionális funkciójának jellemzésére, így az AR kimutatásában is fontos szerepet tölthet be. Néhány nemrégiben megjelent 2D speckle tracking echokardiográfiás vizsgálatában azt találták, hogy a globális longitudinális strain (GLS) akut rejekcióban csökken, illetve GLS értéke normalizálódik az immunszuppresszív terápia során, így alkalmas lehet a terápiás válasz nyomonkövetésére $(30,31)$.

\section{Szív MR-vizsgálat}

A szív MR-vizsgálat szintén noninvazív, képalkotó eljárás, amely a bal, illetve jobb kamrai volumenek, illetve izomtömeg meghatározásának referenciamódszere, továbbá speciális MR-szekvenciák és kontrasztanyag alkalmazásával szövetspecifikus információt nyújt. Mindezek révén a CMR-vizsgálattal lehetőségünk van a szívizomzatot érintő gyulladás, illetve nekrózis kimutatására, amely folyamatok AR-ben is megfigyelhetőek, ezáltal alkalmas módszer lehet az akut rejekció kimutatásában. Az EMB-vel szemben a teljes szívizomzat megítélését lehetővé teszi, és mivel nem jár ionizáló sugárzással, szükség szerint többször ismételhető.

Az új kiértékelő szoftverek segítségével lehetőségünk nyílt az echokardiográfiához hasonlóan különböző strainértékék meghatározására a rövid- és hossztengelyi mozgó felvételek alapján, amelyek szintén értékes információt hordozhatnak az AR megítélésében.

\section{$\mathrm{T}_{2}$-súlyozott mérések}

A szívizomzatot érintő ödéma megítélésére a hagyományosan használt $\mathrm{T}_{2}$-súlyozott felvételek alapján számolt miokardiális ödéma arány (a szívizom és vázizomzat jelintenzitásának aránya) nem kellően megbízható az akut rejekció megítélésében (32-34), habár egy korábbi vizsgálatban Krieghoff és társai az ödéma arány esetén 93\%-os negatív prediktív értéket állapítottak meg (20).

\section{$\mathrm{T}_{2}$ mapping}

Az AR diagnosztikájában az egyik leginkább vizsgált CMR-paraméter a $T_{2}$ relaxációs idő, amelynek értéke egyenesen arányos a szívizomzat víztartalmával, így 
az AR-ben megfigyelhető ödéma miatt a $T_{2}$ idő megnyúlása várható. Több transzplantációs állatmodellben a $T_{2}$ relaxációs idő pozitív korrelációt mutatott az AR szövettani súlyossága, valamint az ex vivo vizsgált szívizomzat víztartalma között $(32,33)$. A $\mathrm{T}_{2}$ mapping technika kvantitatív értékelést is lehetővé tesz, amely során a szívizomzat minden pontjának $T_{2}$ relaxációs ideje meghatározható. Ez az eljárás már megbízhatóbb, erősebb evidenciával rendelkezik az előző paraméterhez képest. Marie és munkatársai rejekciós betegek CMR-vizsgálata során kimutatta, hogy amenynyiben a $\mathrm{T}_{2}$ idő megnyúlás nagyobb mint $56 \mathrm{msec}$, úgy az $97 \%$-os negatív prediktív értékü és $89 \%$-os szenzitivitású, valamint $70 \%$-os specificitású a közepes fokú ( $\geq$ grade $2 \mathrm{R}$ ) rejekció kimutatásában, az EMB-hez viszonyítva (24). Azonban a vizsgálatban csak AR gyanús betegeket vontak be, így a $\mathrm{T}_{2}$ mapping valós diagnosztikus pontossága még mindig nem kellően ismert. $\mathrm{A} \mathrm{T}_{2}$ mapping alkalmazásakor figyelembe kell vennünk, hogy értéke a transzplantációt követő első 25 napban is megnyúlik, amelyet valószínúleg iszkémiás-repefúziós károsodás magyarázhat, így alkalmazása ebben az időszakban nem kellően megbízható (35). Kimutatták továbbá, hogy a biopszia negatív allograftok esetén magasabb $\mathrm{T}_{2}$ idő mérhető az azonos korú kontrollokhoz képest (36). A módszer limitációjaként kell megemlíteni, hogy az alacsony jel-zaj arány és a mozgási mütermékek a $T_{2}$ mérések reprodukálhatóságát és pontosságát csökkenthetik (3).

\section{$T_{1}$-súlyozott mérések}

Intravénás kontrasztanyag adását követően lehetőségünk van az ún. korai fázisú $T_{1}$-súlyozott felvételek készítésére, amely az akut rejekcióval járó gyulladásos hyperaemia kimutatására alkalmas. Ez a módszer a hagyományos $\mathrm{T}_{2}$-súlyozott felvételekhez hasonlóan inkább kvalitatív kiértékelést tesz lehetővé, de lehetőségünk van az ún. globális relatív halmozás (GRH) mérésére is, amely a myocardium és a vázizomzat jelintenzitásának aránya. A GRH diagnosztikus szerepe az ödéma-arányhoz hasonlóan ellentmondásos a különböző tanulmányokban az AR kimutatásában, bár egy kisebb elemszámú tanulmányban (37) a GRH szignifikánsabb magasabb volt a grade $2 \mathrm{R}$-es AR esetén, mint a grade 1R rejekcióban.

A miokardiális nekrózist/fibrózist jelző késői típusú kontraszthalmozás és az AR kapcsolatáról kevesebb irodalmi adat áll rendelkezésünkre. Szívtranszplantált betegek körében a késői halmozás előfordulásának pontos prevalenciája nem ismert, azonban egyes kisebb elemszámú tanulmány $71 \%$-os prevalenciáról is beszámolt (38). Ebben a vizsgálatban 89 HTX beteget vizsgáltak szív MR-vizsgálattal, leggyakrabban fátyolos jellegủ noniszkémiás halmozás ábrázolódott, a leggyakoribb lokalizáció az interventrikuláris szeptum volt. A szívtranszplantált betegeknél megfigyelhető késői halmozás hátterében azonban az AR mellett allograft vasculopathia és reperfúziós károsodás is állhat (3). A rendelkezésünkre álló kevés irodalmi adat alapján a késői kontraszthalmozás és AR közötti viszony ellentmondásos, egyes cikkek nem találtak korrelációt a rejekció jelenléte és súlyossága, valamint a késői halmozás megléte között $(3,14,19)$. Ezzel szemben Butler és munkatársai a HTX-betegek utánkövetése során a miokardiális heg jelenlétét a kardiovaszkuláris halálozás és hospitalizáció független prediktorának találták (39).

\section{$T_{1}$ mapping}

A $T_{2}$ mappinghez hasonlóan, a szívizomzat különböző pontjainak $\mathrm{T}_{1}$ ideje mind natívan mind kontrasztanyag adását követően egyaránt meghatározható, amely alapján még részletesebb információt kaphatunk a szívizomzat sejtszintü folyamatairól. $A T_{1}$ idő érzékeny a myocardium víztartalmának változására, így az akut rejekcióban fellépő ödéma következtében a natív $T_{1}$ idő növekszik (40), így ezen érték is segítségünkre lehet a rejekció megítélésében. Itt is figyelembe kell vennünk, hogy a $T_{1}$ idő értéke az első évben a $T_{2}$ időhöz hasonló csökkenő tendenciát mutat (41). $A T_{1}$ idő és az akut rejekció kapcsolatának vizsgálatában kevés és ellentmondásos adat áll rendelkezésre, Miller és társai tanulmányában a $T_{1}$ idő tekintetében tendencia mutatkozott a grade $2 \mathrm{R}$ és grade $0 \mathrm{R}-1 \mathrm{R}$ rejekció elkülönítésében (41).

\section{Stressz MR-vizsgálat}

Farmakológiai ágensekkel végzett terheléses MR-vizsgálat lehet inotróp (pl. dobutamin) vagy vazodilatátoros (adenozin, dipiridamol, regadenozon stb.). Dobutaminterhelés során a szívizomzat kontraktilitásának fokozásán keresztül a myocardium oxigénigénye is növekszik, a miokardiális iszkémiát falmozgászavarként detektáljuk. Az adenozin stressz perfúziós mérések során a különböző kiértékelő szoftverek segítségével lehetőségünk nyílik a myocardium véráramlásának kvalitatív és kvantitatív elemzésére is (42). Adenozinnal végzett stressz perfúziós vizsgálatokban az invazív angiográfiás mérésekkel megegyezően a miokardiális véráramlás csökkenését találták azoknál a HTX-betegeknél, akik korábban átestek már rejekción (43-45). Kevert típusú AR CMR jellegzetességeiről részletes leírás az irodalomban nem található.

\section{Megbeszélés}

Az AR diagnosztikájának referenciamódszere továbbra is az invazív endomiokardiális biopszia, a diagnózis felállítása a nemzetközi Szív- és Tüdőtranszplantációs Társaság (ISHLT) által meghatározott kritériumok alapján történik (9-11). Az EMB azonban néhány limitációval is rendelkezik az AR diagnosztikájában. Ezek közül legfontosabb, hogy bár az interventrikuláris szeptum több pontjáról történik a mintavétel, nem a teljes szívizomzatról nyújt információt, így a rejekcióra jellemző 
foltos érintettség miatt az esetek akár 20\%-ában álnegatív eredményt adhat (3). Mindezek miatt egyre inkább olyan diagnosztikus eljárások kerülnek előtérbe, amelyek noninvazívak, lehetővé teszik a bal és jobb kamra teljes ábrázolását, valamint segítségükkel funkcionális információkhoz juthatunk. Ezen eljárások közül kiemelkedik a szív MR-vizsgálat, amely a fentieken túl a különböző szekvenciák valamint kontrasztanyag alkalmazásával szövetspecifikus információt nyújt (miokardiális ödéma és nekrózis/fibrózis kimutatása). Jól lehet relatív kevés és kis elemszámú irodalmi adat áll a rendelkezésünkre, a HTX-es betegekkel folyatott CMR-kutatások során a $T_{2}$ mapping technika bizonyult a legígéretesebb módszernek az AR kimutatására, amelynek értéke a különböző kutatások szerint korrelál az akut rejekció súlyosságával, így nem csak az AR diagnosztikájában, de a terápia hatékonyságának nyomonkövetésére is alkalmas lehet. Saját betegeink CMR-vizsgálatainak limitációjaként említhető, hogy bár végeztünk $\mathrm{T}_{2}$-méréseket az ödéma megítélésére, azonban technikai okok miatt $T_{1}$ és $T_{2}$ mapping elvégzésére nem volt lehetőségünk. Kevert típusú AR CMR jellegzetességeiről részletes leírás az irodalomban ezidáig nem található. Mindhárom, kevert rejekció miatt vizsgált beteg esetén látott CMR-eltérések csaknem identikusak voltak, és EMB-k eredménye alapján akut kevert rejekció részjelenségeinek tarthatóak: az interventrikuláris szeptumot, alsó és felső inzerciós zónát, a jobb kamra szabad falát és rekeszi felszínét érintő subepi- és midmiokardialis ödéma és késői kontraszthalmozás, amelyet a bal kamra inferior és laterális fala, valamint a jobb kamra szabad fala és rekeszi felszíne mentén jelentkező perikardiális halmozás is kísért.

\section{Következtetések}

Összefoglalva elmondhatjuk, hogy a CMR-vizsgálat ígéretes módszer lehet az AR kimutatásában. Amenynyiben az eredményeket nagy elemszámú, multicentrikus vizsgálatok megerősítik, úgy a rutin EMB száma csökkenhet és a jövőben a CMR válhat a szívtranszplantált betegek noninvazív „biopsziájává”.

\section{Köszönetnyilvánítás}

Tekintettel arra, hogy a szívtranszplantált betegek igen komplex, több diszciplínán átívelő ellátásban részesülnek, ezúton szeretnénk megköszönni mindazon kolléga aktív munkáját, akik részt vettek és vesznek ezen betegek ellátásában és gondozásában.

\section{Irodalom}

1. Hertz MI, Aurora P, Christie JD, et al. Scientific Registry of the International Society for Heart and Lung Transplantation: introduction to the 2009 Annual Reports. J Heart Lung Transplant 2009;
28(10): 989-92. doi: 10.1016/j.healun.2009.08.005. PubMed PMID: 19782281.

2. Lindenfeld J, Miller GG, Shakar SF, et al. Drug therapy in the heart transplant recipient: part II: immunosuppressive drugs. Circulation 2004; 110(25): 3858-65. doi: 10.1161/01.CIR.0000150332.42276.69. PubMed PMID: 15611389.

3. Miller CA, Fildes JE, Ray SG, et al. Non-invasive approaches for the diagnosis of acute cardiac allograft rejection. Heart 2013; 99(7): 445-53. doi: 10.1136/heartjnl-2012-302759. PubMed PMID: 23257172.

4. Stehlik J, Edwards LB, Kucheryavaya AY, et al. The Registry of the International Society for Heart and Lung Transplantation: twenty-seventh official adult heart transplant report -2010 . J Heart Lung Transplant 2010; 29(10): 108103. doi: 10.1016/j.healun.2010.08.007. PubMed PMID: 20870164.

5. Nair N, Ball T, Uber PA, Mehra MR. Current and future challenges in therapy for antibody-mediated rejection. J Heart Lung Transplant. 2011; 30(6): 612-7. doi: 10.1016/j.healun.2011.02.002. PubMed PMID: 21474341.

6. Michaels PJ, Espejo ML, Kobashigawa J, al. Humoral rejection in cardiac transplantation: risk factors, hemodynamic consequences and relationship to transplant coronary artery disease. J Heart Lung Transplant 2003; 22(1): 58-69. PubMed PMID: 12531414.

7. Wu GW, Kobashigawa JA, Fishbein MC, et al. Asymptomatic antibody-mediated rejection after heart transplantation predicts poor outcomes. J Heart Lung Transplant 2009; 28(5): 417-22. doi: 10.1016/j.healun.2009.01.015. PubMed PMID: 19416767; PubMed Central PMCID: PMCPMC3829690.

8. Kfoury AG, Miller DV, Snow GL, et al. Mixed cellular and antibody-mediated rejection in heart transplantation: In-depth pathologic and clinical observations. J Heart Lung Transplant 2016; 35(3): 33541. doi: 10.1016/j.healun.2015.10.016. PubMed PMID: 26586489.

9. Berry GJ, Burke MM, Andersen C, et al. The 2013 International Society for Heart and Lung Transplantation Working Formulation for the standardization of nomenclature in the pathologic diagnosis of antibody-mediated rejection in heart transplantation. $\mathrm{J}$ Heart Lung Transplant 2013; 32(12): 1147-62. doi: 10.1016/j.healun.2013.08.011. PubMed PMID: 24263017.

10. Stewart S, Winters GL, Fishbein MC, et al. Revision of the 1990 working formulation for the standardization of nomenclature in the diagnosis of heart rejection. J Heart Lung Transplant 2005; 24(11): 1710-20. doi: 10.1016/j.healun.2005.03.019. PubMed PMID: 16297770.

11. Winters GL, Marboe CC, Billingham ME. The International Society for Heart and Lung Transplantation grading system for heart transplant biopsy specimens: clarification and commentary. J Heart Lung Transplant 1998; 17(8): 754-60. PubMed PMID: 9730423.

12. Chih S, Chruscinski A, Ross $\mathrm{HJ}$, et al. Antibody-mediated rejection: an evolving entity in heart transplantation. J Transplant 2012; 2012: 210210. doi: 10.1155/2012/210210. PubMed PMID: 22545200; PubMed Central PMCID: PMCPMC3321610.

13. Colvin MM, Cook JL, Chang $P$, et al. Antibody-mediated rejection in cardiac transplantation: emerging knowledge in diagnosis and management: a scientific statement from the American Heart Association. Circulation 2015; 131(18): 1608-39. doi: 10.1161/ CIR.0000000000000093. PubMed PMID: 25838326

14. Butler CR, Savu A, Bakal JA, et al. Correlation of cardiovascular magnetic resonance imaging findings and endomyocardial biopsy results in patients undergoing screening for heart transplant rejection. J Heart Lung Transplant 2015; 34(5): 643-50. doi: 10.1016/j. healun.2014.12.020. PubMed PMID: 25934478.

15. Zeglen S, Zakliczynski M, Wozniak-Grygiel E, et al. Mixed cellular and humoral acute rejection in elective biopsies from heart transplant recipients. Transplant Proc 2009; 41(8): 3202-5. doi: 10.1016/j. transproceed.2009.08.028. PubMed PMID: 19857710. 
16. Saraiva F, Matos V, Goncalves L, et al. Complications of endomyocardial biopsy in heart transplant patients: a retrospective study of 2117 consecutive procedures. Transplant Proc 2011; 43(5): 1908-12. doi: 10.1016/j.transproceed.2011.03.010. PubMed PMID: 21693299

17. Spiegelhalter DJ, Stovin PG. An analysis of repeated biopsies following cardiac transplantation. Stat Med 1983; 2(1): 33-40. PubMed PMID: 6359316.

18. Baraldi-Junkins C, Levin HR, Kasper EK, et al. Complications of endomyocardial biopsy in heart transplant patients. J Heart Lung Transplant 1993; 12 (1 Pt 1): 63-7. PubMed PMID: 8443204.

19. Simsek E, Nalbantgil S, Ceylan N, et al. Diagnostic performance of late gadolinium enhancement in the assessment of acute cellular rejection after heart transplantation. Anatol J Cardiol 2016; 16(2): 113-8. doi: 10.5152/AnatolJCardiol.2015.5961. PubMed PMID: 26467370; PubMed Central PMCID: PMCPMC5336724.

20. Krieghoff C, Barten MJ, Hildebrand L, et al. Assessment of sub-clinical acute cellular rejection after heart transplantation: comparison of cardiac magnetic resonance imaging and endomyocardial biopsy. Eur Radiol 2014; 24(10): 2360-71. doi: 10.1007/s00330-0143246-2. PubMed PMID: 24895035; PubMed Central PMCID: PMCPMC4155184.

21. Fishbein MC, Kobashigawa J. Biopsy-negative cardiac transplant rejection: etiology, diagnosis, and therapy. Curr Opin Cardiol 2004; 19(2): 166-9. PubMed PMID: 15075746.

22. F Perner GP. Szervátültetés. Medicina2013.

23. Butler CR, Thompson R, Haykowsky M, et al. Cardiovascular magnetic resonance in the diagnosis of acute heart transplant rejection: a review. J Cardiovasc Magn Reson 2009; 11: 7. doi: 10.1186/1532-429X-11-7. PubMed PMID: 19284612; PubMed Central PMCID: PMCPMC2660322.

24. Marie PY, Angioi M, Carteaux JP, et al. Detection and prediction of acute heart transplant rejection with the myocardial T2 determination provided by a black-blood magnetic resonance imaging sequence. J Am Coll Cardiol 2001; 37(3): 825-31. PubMed PMID: 11693758.

25. Desruennes M, Corcos T, Cabrol A, et al. Doppler echocardiography for the diagnosis of acute cardiac allograft rejection. J Am Coll Cardiol 1988; 12(1): 63-70. PubMed PMID: 3288679.

26. Valantine HA, Yeoh TK, Gibbons R, et al. Sensitivity and specificity of diastolic indexes for rejection surveillance: temporal correlation with endomyocardial biopsy. J Heart Lung Transplant 1991; 10(5 Pt 1): 757-65. PubMed PMID: 1958683.

27. Moidl R, Chevtchik $O$, Simon $P$, et al. Noninvasive monitoring of peak filling rate with acoustic quantification echocardiography accurately detects acute cardiac allograft rejection. J Heart Lung Transplant 1999; 18(3): 194-201. PubMed PMID: 10328144.

28. Vivekananthan $\mathrm{K}$, Kalapura $\mathrm{T}$, Mehra M, et al. Usefulness of the combined index of systolic and diastolic myocardial performance to identify cardiac allograft rejection. Am J Cardiol 2002; 90(5): 517-20. PubMed PMID: 12208413.

29. Lu W, Zheng J, Pan X, Sun L. Diagnostic performance of echocardiography for the detection of acute cardiac allograft rejection: a systematic review and meta-analysis. PLoS One 2015; 10(3): e0121228. doi: 10.1371/journal.pone.0121228. PubMed PMID: 25822627; PubMed Central PMCID: PMCPMC4378940.

30. Clemmensen TS, Logstrup BB, Eiskjaer H, Poulsen SH. Changes in longitudinal myocardial deformation during acute cardiac rejection: the clinical role of two-dimensional speckle-tracking echocardiography. J Am Soc Echocardiogr 2015; 28(3): 330-9. doi: 10.1016/j.echo.2014.10.015. PubMed PMID: 25499656.

31. Du GQ, Hsiung MC, Wu Y, Qu SH, et al. Three-Dimensional Speckle-Tracking Echocardiographic Monitoring of Acute Rejection in Heart Transplant Recipients. J Ultrasound Med 2016; 35(6): 116776. doi: 10.7863/ultra.15.07013. PubMed PMID: 27105950

32. Revel D, Chapelon C, Mathieu D, et al. Magnetic resonance imaging of human orthotopic heart transplantation: correlation with endomyocardial biopsy. J Heart Transplant 1989; 8(2): 139-46. PubMed PMID: 2651617.

33. Smart FW, Young JB, Weilbaecher D, et al. Magnetic resonance imaging for assessment of tissue rejection after heterotopic heart transplantation. J Heart Lung Transplant 1993; 12(3): 403-10. PubMed PMID: 8329410.

34. Almenar L, Igual B, Martinez-Dolz L, et al. Utility of cardiac magnetic resonance imaging for the diagnosis of heart transplant rejection. Transplant Proc 2003; 35(5): 1962-4. PubMed PMID: 12962864. 35. Wisenberg G, Pflugfelder PW, Kostuk WJ, et al. Diagnostic applicability of magnetic resonance imaging in assessing human cardiac allograft rejection. Am J Cardiol 1987; 60(1): 130-6. PubMed PMID: 3300244.

36. Markl M, Rustogi R, Galizia M, et al. Myocardial T2-mapping and velocity mapping: changes in regional left ventricular structure and function after heart transplantation. Magn Reson Med 2013; 70(2): 517-26. doi: 10.1002/mrm.24472. PubMed PMID: 23008092.

37. Taylor AJ, Vaddadi G, Pfluger H, et al. Diagnostic performance of multisequential cardiac magnetic resonance imaging in acute cardiac allograft rejection. Eur J Heart Fail 2010; 12(1): 45-51. doi: 10.1093/eurjhf/hfp174. PubMed PMID: 20023044; PubMed Central PMCID: PMCPMC2796145.

38. Braggion-Santos MF, Andre F, Lossnitzer D, et al. Prevalence of different forms of infarct-atypical late gadolinium enhancement in patients early and late after heart transplantation. Clin Res Cardiol 2014; 103(1): 57-63. doi: 10.1007/s00392-013-0623-9. PubMed PMID: 24122145.

39. Butler CR, Kim DH, Chow K, Toma M, et al. Cardiovascular MRI predicts 5-year adverse clinical outcome in heart transplant recipients. Am J Transplant 2014; 14(9): 2055-61. doi: 10.1111/ajt.12811. PubMed PMID: 25100504.

40. Haaf P, Garg P, Messroghli DR, Broadbent DA, et al. T1 Mapping and Extracellular Volume (ECV) in clinical practice: a comprehensive review. J Cardiovasc Magn Reson 2016; 18(1): 89. doi: 10.1186/ s12968-016-0308-4. PubMed PMID: 27899132; PubMed Central PMCID: PMCPMC5129251.

41. Miller CA, Naish JH, Shaw SM, et al. Multiparametric cardiovascular magnetic resonance surveillance of acute cardiac allograft rejection and characterisation of transplantation-associated myocardial injury: a pilot study. J Cardiovasc Magn Reson 2014; 16: 52. doi: 10.1186/s12968-014-0052-6. PubMed PMID: 25160654; PubMed Central PMCID: PMCPMC4121512.

42. Hamirani YS, Kramer CM. Cardiac MRI assessment of myocardial perfusion. Future Cardiol 2014; 10(3): 349-58. doi: 10.2217/ fca.14.18. PubMed PMID: 24976472; PubMed Central PMCID: PMCPMC4152773.

43. Nitenberg A, Tavolaro O, Loisance D, et al. Maximal coronary vasodilator capacity of orthotopic heart transplants in patients with and without rejection. Am J Cardiol 1989; 64(8): 513-8. PubMed PMID: 2672759.

44. Muehling OM, Wilke NM, Panse $P$, et al. Reduced myocardial perfusion reserve and transmural perfusion gradient in heart transplant arteriopathy assessed by magnetic resonance imaging. J Am Coll Cardiol 2003; 42(6): 1054-60. PubMed PMID: 13678930.

45. Rivard AL, Swingen CM, Blake D, et al. A comparison of myocardial perfusion and rejection in cardiac transplant patients. Int $\mathrm{J}$ Cardiovasc Imaging 2007; 23(5): 575-82. doi: 10.1007/s10554-0069184-6. PubMed PMID: 17206459 